\section{Logo Shape and Color as Drivers of Change in Brand Evaluation and Recognition}

\author{
Matia Torbarina \\ University of Rijeka, Faculty of Economics and Business, Croatia \\ matia.torbarina@efri.hr \\ Nina Grgurić Čop \\ University of Rijeka, Faculty of Economics and Business, Croatia \\ nina.grguric.cop@efri.hr

\section{Lara Jelenc} \\ University of Rijeka, Faculty of Economics and Business, Croatia \\ lara.jelenc@efri.hr
}

\begin{abstract}
The purpose of the present study was to test whether logo shape and color affect emotional and cognitive response to a new logo. In the explorative part of the study, the effect of the amount of each of the additive primary color on logo perception was examined. Research was done on a sample of 190 students whose ratings were used as logo description measures. Two independent variables used in the study were logo shape (abstract vs. concrete) and logo color (original color vs. greyscale). Results showed that greyscale logos and logos that are concrete were recognized more accurately while liking was not related to either independent variable. It was also observed that the amount of red color in logo is negatively (correlated/related), and blue and green color are positively related to both logo recognition and logo liking. Practitioners are advised to note that factors affecting consumers' cognition and emotion are different. Scientists can extend findings on the effect of amount of individual colors in a logo. This is one of the first works of research that examined the effect of logo color on brand recognition and has approached studying color in this way of averaging amount of each of the additive primary colors. External validity of the research is enhanced by testing the younger generation in their natural habitat of mobile phone environment.
\end{abstract}

Keywords: corporate logo, brand awareness, logo likability, logo color, logo shape

\section{Introduction}

Brand logo is considered to be one of the most salient and important parts of corporate visual identity (Adir et al., 2012), which can lead to consumers' affective reactions before carrying out any promotional activity (Bresciani \& Del Ponte, 2017). For it to be effective and appealing, logo creation is usually entrusted to specialized designers. The problem with this kind of logo creation is that specialized designers rarely do any impression-creation research, and even if they
ORIGINAL SCIENTIFIC PAPER

RECEIVED: MARCH 2020

REVISED: DECEMBER 2020

ACCEPTED: FEBRUARY 2021

DOI: 10.2478/ngoe-2021-0004

UDK: 659.126

JEL: M30 M31 M37

Citation: Torbarina, M., Grgurić Čop, N., \& Jelenc, L. (2021). Logo Shape and Color as Drivers of Change in Brand Evaluation and Recognition.Naše gospodarstvo/Our Economy, 67(1), 33-45. DOI: 10.2478/ngoe-2021-0004
NAŠE GOSPODARSTVO OUR ECONOMY

\section{\begin{tabular}{l|l|l} 
Vol.67 No.1 2021 \\
\hline
\end{tabular}}

pp. $33-45$ 
do, it is questionable how prone they would be to share their results with their colleagues and scientific community since their work is commercial and not free (Colman, 1995). Few designers that are willing to share their logo creation process state that it all starts from a pool of shapes from which they select those that elicit positive affect and meaning (Henderson \& Cote, 1998). This conflict between the designers and scientists is still present and is rooted in the basic epistemology; designers are focused on creation while scientists aim for discovery (Peralta \& Moultrie, 2010). Others have noted practitioners rarely use conceptual tools which are recommended by academics (Boiling et al., 2017). Greater blame has been assigned to scientists for their lack of accurate and easily understandable communication (Cheng \& Rolandi, 2015; Khoury et al., 2019).

The logo design and selection process can be expensive due to the numerous tasks and employees that need to be engaged. For example, initial design and (re)placing the logo on everything from business cards to signage on buildings (Pimentel, 1997; as cited in Henderson \& Cote, 1998) are only a few activities that add to the total costs of this action. On the other side, the primary goal of advertising, especially in the early stages of a brand/product introduction, is to build brand awareness, or getting the consumers to be able to recall or recognize a brand (Business Dictionary, $\mathrm{n}$. d). Due to the rapid growth of new brands, over 40 million brands are registered all over the world (WIPO, 2019), and brand awareness became even more important for leaving a distinctive footprint in consumers' minds. To help brands understand how to achieve better recognition in a cluttered digital environment, researchers need to understand why some brands are more recognizable than others. On top of that, the positive effect of logo perception on customers' commitment and consequentially on firm performance is not derived from merely being able to identify the brand, but also by offering aesthetic appeal (Park et al., 2013): to build a strong customer mindset brand equity (Ye \& Van Raaij, 2004), another element needs to be considered brand liking.

Despite the obvious link with brand awareness and the fact that a likable logo can mean future budget-saving for a company, not much research attention has been devoted to investigating which corporate logo characteristics affect perception of firms' visual identity. For instance, there are guidelines for selecting and modifying logos (Henderson \& Cote, 1998). But they were broadly stated without describing which specific logo features lead to higher recognition. That is why in their later work they called for more research on both logo color and shape as predictors of branding outcomes (Henderson et al., 2003). The research on logo recognition took various turns since, from estimating its alignment with company's mission (Hynes, 2008) to doing research on an existing logo, such as Apple's logo (Blake, 2015). Recent studies have tried to explain how logos are recognized in social network images. Wang et al. (2014) acknowledged the importance of logo recognition (Mehta \& Purvis, 2006) and explained how consumers react to changes in design of existing logos (Machado et al. 2012, Machado et al., 2015). However, none focused on how specific logo features can enhance likability and recognition in the future. One of the design features that is often featured in studies is the color (Dowling, 1994). But researchers mostly focused on the appropriateness of color (Bottomley \& Doyle, 2016) or its meaning (Hynes, 2008). More recent studies have focused on specific nichelike fashion blogs (Ridgway \& Beth Myers, 2013) with findings that cannot be generalized to all the logo research.

In contrast to previous research, present research aims to offer more general information on how these logo features impact brand awareness determinants (brand recognition) and likability by discerning logo color and shape from other brand cues. Importance of recognition as a brand awareness measure is emphasized by researchers' efforts to devise a technique based on feature binding to enhance logo recognition (Romberg \& Lienhart, 2013).

The present paper's purpose is contribution to the nascent literature on logo characteristics and its effect on important marketing outcomes such as brand awareness in the digital environment. It will be done through examination of how specific brand logo characteristics affect its likeability (i. e. elicits emotional response) and recognizability (i. e. cognitive response) in a crowded, digital environment. Although like previous research on logo design, the present study differs in a couple of ways. First, the research design includes color, shape, recognition, and likeability of the logo. Second, the authors are not aware of any previous research that empirically tested for the relationship between color and recognizability. Third, contrary to existing research on color, the authors of this study propose a more objective way of measuring color in each logo - as an average amount of additive primary colors used on television and computer screens (red, green, blue). Finally, the study's design enhances the external validity of the observed results by placing the research in the environment in which respondents are most familiar with - their smartphones.

The following section will describe key concepts used in the research. Methodology and results sections are followed by a discussion of the most important results together with implications and research limitations. 


\section{Theoretical Background and Hypotheses Development}

\section{Corporate logo as a key corporate brand likability and awareness determinant}

The definition of brand awareness mentioned in the introduction makes a clear distinction between recollection and recognition, which is in line with how other authors (Belch \& Belch, 2018) view indicators of brand awareness: unaided recall and aided brand recall. Original brand awareness definition states that it is a reflection of presence of the brand in the mind of consumers which plays a key role in determining brand equity (Aaker, 1998). This definition, and especially the way in which it is measured, is grounded in the Atkinson-Shiffrin model of memory (Atkinson \& Shiffrin, 1968). According to this model, recognition represents perceiving something as previously known (Mandler, 1980) and is considered to be an easier task than recollection. Experiments conducted in 1968 by Atkinson and Shiffrin showed that subjects who were not able to recall an answer but were able to choose the correct answer among a set of alternatives, showed a high level of accuracy in recognition. That is why examining the antecedents that drive and increase logo recognizability is an important issue in branding and advertising.

Regardless of the cultural aspect, when a firm finds itself in the low-investment setting, one of the few cues that can differentiate them is the affect attached to a logo (Machado et al., 2015). Research on known corporate logos showed that the congruency of design elements (i.e. both brand components were evaluated similarly in terms of shape symbolism) was more frequently related to emotional engagement and consequently to positive emotions (Salgado-Montejo et al., 2014). Corporate visual identity positively affects, through logo design, a firm's visibility, distinctiveness, authenticity, transparency, and consistency (Van den Bosch et al., 2005). Being well-aware the "quality of design" would be nearly impossible to examine in a single piece of research. This research builds upon the existing research on logo color and shape in trying to provide a deeper understanding on some missing or still ambiguous effects logo design has on brand likability and recognizability.

Brand liking and recognizability are determinants of consumer mind brand equity (Ye \& Van Raaij, 2004). Brand awareness of a corporate brand is a dominant choice heuristic among subjects, emphasizing that building brand awareness was an important strategy for advertising if brands want to increase probability to be chosen (Hoyer \&
Brown, 1990). Due to the corporate brand logo's effect on brand awareness through eliciting favorable, unique associations (Girard et al., 2013; van Grinsven \& Das, 2016), examination of the prerequisites and consequences of a likable logo is of great academic and practical importance. The environment is quickly changing and brands are adjusting their business to millennials who show different behavior patterns than previous generations (Črešnar \& Jevšenak, 2019). Younger consumers spend most of their time online (Emarketer, 2019) which leads to attentional saturation. This difficulty in memorizing most of the things they are exposed to became an important determinant of young generations (Blake et al., 2015). Importance of favorable logo (i.e. one with likable corporate name, shape and typeface) perception on corporate image, recognizability, familiarity and reputation was observed by Foroudi et al. (2014). In the present study, a closer look is given to how likability and recognizability can be affected by two corporate logo design components - color and shape.

\section{Logo color and likability}

Many promotional channels and forms of communication are perceived as either a signal or noise to different consumers (Belch \& Belch, 2018). For this reason, it is important to get the most out of every logo-consumer contact, and the first step towards this goal is having a corporate logo that people like. The simplest form of differentiation when it comes to studying color is grayscale vs original color. In their guidelines for logo creation, Henderson and Cote (1998) emphasized preliminary evidence suggests that color greatly affects the perception of design. Color also plays a big role in driving brand personality (Labrecque \& Milne, 2012; Ridgway \& Myers, 2014) and signalizes affiliation to the specific industry sector (O’Connor, 2011), making it easier to position a brand in a complex macro environment and consumers' minds. But, when studying color in marketing, researchers mostly focused on its appropriateness rather than likability: an appropriately chosen color for a corporate logo can bring inherent and immediate value to a brand (Bottomley \& Doyle, 2006; Hynes, 2009). There was, however, exploratory research done on the effect logo color has on likability (Labrecque \& Milne, 2012). Results suggested that addition of a color enhanced logo likability. Despite its valuable findings in directing the role of color in branding, it was done using existing corporate brands' logos, which have their own, pre-existing brand likability and consumers' experiences with brands. To extrapolate the effect color plays in logo likability by using unknown logos, we propose the following:

H1: Colored logos will be liked more than grayscale ones. 


\section{Logo shape and likability}

Logos shapes have been at the focus of numerous studies for many years now (e.g. Henderson \& Cote, 1998; Bottomley \& Doyle, 2006). They observed that concrete, figurative, or natural shapes are those that resemble real-life objects - something people are usually exposed to (such as letters or objects). Abstract shapes, on the other hand, do not resemble anything people usually see. An example of concrete and abstract logos used in the present research is shown in Figure 1.

Figure 1. Examples of abstract and concrete logos used in the study

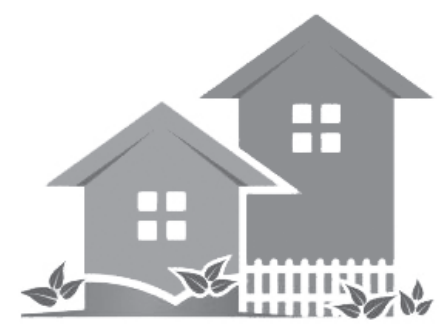

Concrete logo

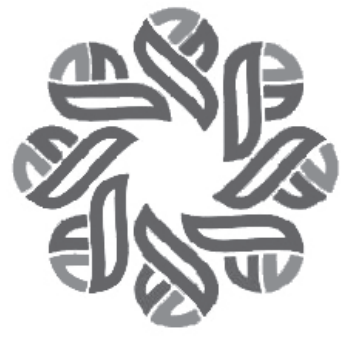

Abstract logo
Source: Behance, n.d.

By using stimulus codability, a term used in psychology to describe notions of consensus in meaning, Henderson \& Cote (1998) explained concrete logos that are easily codable, as they remind people of something they have already seen and thus are perceived, interpreted, and retained. Theoretical assumptions stating that that circular shapes activate softness associations and angular shapes activate hardness associations motivated research by Henderson \& Cote (1998) and Jiang et al. (2016). Both papers showed that shape, as the sole feature of the logo, is powerful enough to affect perceptions of a company's attributes. But there was not much data on whether respondents liked what they had seen. Nevertheless, their conclusions were the steppingstones for further development of research on logo characteristics that need to be emphasized to elicit positive outcomes.

Research on the relationship between logo shape and likeability showed that a logo's sense of nature influences consumers' affective response to the logo (César Machado et al., 2012); the change in the roundedness of a previously angular logo affects brand attitude negatively, but only for strongly committed consumers, whereas weakly committed consumers will react positively to such changes (Walsh et al., 2010; Walsh et al., 2011). These effects are similar across cultures. Surveys conducted in three different coun- tries (Pittard et al., 2007) showed universal preference for divine proportion across cultures, and the biggest effect was observed for logos resembling forms found in nature. Based on these findings, the following hypotheses are proposed:

H2: Concrete logos will be liked more than abstract ones.

\section{Logo color and recognizability}

Despite color being a hypothesized predictor of many outcomes in marketing literature (eg. Singh, 2006), few, if any, studies have tested its relationship with an important indicator of brand awareness, logo recognition. There are, however, indications that logo color can affect its recognizability. Logo identification is significantly faster for logos presented in color, as opposed to achromatic logos (Tanaka \& Presnell, 1999). Recognition performance increased significantly when face images were presented in color rather than in greyscale (Yip \& Sinha, 2002). The same effect was observed for images of scenery (Wichmann et al., 2002). Finally, color, in general, improves recognition of presented images (Wurm et al., 1993).

\section{H3: Colored logos will be correctly recognized more fre-} quently than grayscale ones.

\section{Logo shape and recognizability}

It has been shown that naturalistic logos (i.e. logos that are formed of recognizable everyday figures) are recognized more correctly than abstract logos (Henderson \& Cote, 1998; Machado et al., 2015). Recognition occurs on two levels: consumers should remember seeing the logo, which is called "correct recognition" and then they should be able to recreate the brand name, "recall phase” (Henderson \& Cote, 1998). Eliciting consumers' sense of recognition without heavy exposure is becoming imperative (Henderson \& Cote, 1998), especially in the low investment setting that is now more common than ever with start-ups gaining in popularity. Recognition was facilitated by brand name being depicted pictorially, rather than in plain text (MacInnis \& Jaworski, 1989). Marketers in both western and eastern cultures report a need to select logo designs that are "elaborate, natural, and harmonious" if they want to be recognized correctly, suggesting recognition overcomes national borders (Henderson et al., 2003). Children also showed higher recognition for logos to which they were more frequently exposed to (Arredondo et al., 2009), meaning they perceive them as being concrete rather than abstract. Brand recognition was also found to be dependent on the number of exposures. Increase in exposure leads to an increase in brand recognition, especially for complex brand logos, thus suggesting shortterm benefits for simple brand logos, and long-term benefits 
for complex logos (van Grinsven \& Das, 2016). Previous research on logo shape and recognition also used existing, well-known logos as stimuli in the study (Machado et al., 2015). By conceptually replicating previous studies with images of unknown logos, authors are extending findings of the previous research. A hypothesis on shape as a driver of brand recognition follows:

H4: Concrete logos will be correctly recognized more frequently than abstract ones.

\section{Examining a relationship between the average amount of the additive primary colors and its effect on brand likability and recognition - exploratory study}

The digital environment is where most consumer-brand encounters take place (Emarketer, 2019). On television and computer screens, the additive primary colors used to project images are red, green and blue (so called RGB model). That means each color displayed on screen is a combination of these three colors. Marketing literature has often gained valuable insights from color studies (Singh, 2006). As for these three colors, it is now known that retail stores need to be blue rather than red (Bellizzi \& Hite's, 1992), as blue is perceived as sincere, dependable, and trustworthy (Jacobs et al., 1991) while red is paired with love and adventure (Jacobs et al., 1991). Blue and green are more positively evaluated than red, although red is perceived to be the most active color (Adams \& Osgood, 1973). Generally, preference for color suggests blue and green are most preferable, while red and yellow are the least preferable colors (Whitfield \& Wiltshire, 1990). However, as no previous research on color used in logo design operationalized colors as a combination of additive primary colors, this part of the research is explorative, focusing on the following research question:

RQ1: How does the amount of each of the primary colors affect logo liking and recognition?

\section{Methodology of Research}

\section{Sample}

The study was done in the spring of 2019, on a convenience sample of 190 participants with mean age 19.66 years (sdage $=1.46$ years), $26 \%$ were male. The sample frame consisted of 307 students enrolled in the first year of their undergraduate studies at the Faculty of Economics and Business making the response rate 61\%. A student population was used for a couple of reasons. First, reports show that students, particularly those between the ages of
18-24, represent an important marketing segment for retailers and brands to communicate about new products/ promotions (Emarketer, 2019). Secondly, studies show that smartphones are the most commonly used devices for this cohort (Biloš et al., 2017), meaning that it represents externally the most valid environment for this population. One half of the sample ( $\mathrm{N}=94$ students) was exposed to logos in grayscale while the other half was exposed to logos in their original color.

\section{Stimuli and procedure}

Stimuli used in the study consisted of images of unknown logos. The reason the authors opted for the unknown logos was to control the brand familiarity, as suggested by previous research on logo design (e.g. Bresciani \& Del Ponte, 2017; Machado et al., 2015). Unknown logos may lead to affective reactions and meaning consensus simply due to the design of the logo rather than any prior experience participants have with it. All logos were sampled from the webpage (Behance, n.d.). Two templates were downloaded, each containing 28 different logos. Four from the first template and six from the second were discarded based on their size. By eliminating them from the analyses, size of the logo was effectively controlled for. Each logo had the same size of $297 \times 230$ pixels. The shape and color were similar for both the logos that were rated and those that were used as distractors. Thus, the observed difference could have arisen solely from the fact that one set had been seen while the other had not. A pre-test was done on a sample of 16 students whose task was to indicate whether they had seen each of the target logos used in the research, without participating in the liking phase. They recognized an average of $1.56 \log$ os (SD = 1.41) out of 24 that were presented, which serves as a successful manipulation check that the logos were, indeed, unknown.

\section{Procedure}

The study began at the start of the class which all the students were obligated to attend. The students were instructed to take out their smartphones and to follow the presented link to the Google Forms questionnaire.

The first phase of the study started with a presentation of 24 logos, the order of which was randomized for each participant. Their task was to rate how much they liked each of the presented logos. All logos were presented simultaneously, and students were free to scroll up and down and rate them at their own pace. After they had rated the logos, the lecture was resumed as usual. Lecture content was not related to research in any way and logos were not mentioned during the lecture. 
Approximately 90 minutes later, at the end of the class, students were asked to follow another Google link to another questionnaire. Unlike the first part of the study, their task in this phase was to indicate which of the 46 (24 original +22 distractor) logos they had seen. The total time needed for completion of the study was approximately five minutes.

\section{Measures}

Authors manipulated two explanatory variables, logo color and logo shape. Logo color, a between-subjects factor, was presented in either the original color or grayscale, while logo shape, within-subjects factor was presented as logo being either concrete or abstract in its' shape. A logo's shape was determined based on an inspection, which was performed by two authors. Inter-rater reliability, expressed as Cohen's kappa, was calculated to be 0,91 , which falls into the category of “almost perfect agreement” (Landis \& Koch, 1972). Authors concluded that eight of the logos can be categorized as being “concrete”, and 16 can be categorized as "abstract” logos.

Key outcome measures were averaged for each logo. These measures consisted of participants' liking of each logo, their recognition of a logo, and the correlation between liking and recognition for each factor. Liking was measured on a 5-point scale where higher numbers indicate higher liking. Logo recognition was measured as a binary variable with values of 0 (not recognized) and 1 (correctly recognized). Correlation between recognition and liking for each factor represents how they are related to each other, or in other words, how much variance they share among themselves.

Additionally, the average amount of the additive primary colors, red, green and blue, was calculated for each colored logo. O’Connor (2011) suggests using these three colors for several reasons. First, they can be easily assessed with computer software which makes it easy to translate their values into any color. Furthermore, the RGB (red, green, blue) system offers an opportunity to be reproduced across several computer programs such as Word, Excel, and Powerpoint. Finally, color data can be easily arranged and grouped, which enables the identification of similar patterns. These colors represent popular primaries for additive color mixing used in LCD screens, for example (http://rit-mcsl.org/fairchild/WhyIsColor/shortAs.html). Amount of color was measured on 0-255 which corresponds to a scale commonly used by Microsoft programs for color customization. Average amount was calculated by breaking down the logo image into pixels using the "imager” package (Barthelme, 2019). Each logo had approximately 60.000 pixels. The amount of the color in each of them was averaged across all pixels, which resulted in a single estimation of the average amount of red, green, and blue color in each of them. White pixels (all three colors at their maximum) were excluded from the analysis since they represent the logo background and not the logo itself.

\section{Results}

All analyses were down within the $\mathrm{R}$ statistical environment (R Core Team, 2016). Visualizations were created using the "ggplot2" package (Wickham, 2016) and the amount of color in each logo was calculated with the help of "imager" (Barthelme, 2019). Code necessary for analysis reproduction can be found in the Open Science Framework repository (https://osf.io/g9qwj) along with the database and stimuli used following open data suggestions by Houtkoop et al. (2018).

A description of the used measures for each level of explanatory variables is presented in Table 1.

H1 and H2 were tested with a two-way mixed design analysis of variance. Results are presented in Table 2. Rating of a logo liking is independent of both the shape and color $\left(\mathrm{F}_{2,45}=0.71 ; \mathrm{p}>0.05\right)$. Conversely, recognition differs based on logo characteristics and the way in which it is presented $\left(\mathrm{F}_{2,45}=17.34 ; \mathrm{p}<0.01\right)$.

Table 1. Descriptive statistics

\begin{tabular}{|c|c|c|c|c|}
\hline & & $\mathbf{n}$ & M & SD \\
\hline \multirow[t]{4}{*}{ Abstract } & $\begin{array}{l}\text { Correlation of liking } \\
\text { and recognition }\end{array}$ & 32 & 0.01 & 0.13 \\
\hline & Liking & 32 & 2.88 & 0.49 \\
\hline & Recognition & 32 & 0.62 & 0.13 \\
\hline & Recognition variability & 32 & 0.47 & 0.06 \\
\hline \multirow[t]{4}{*}{ Concrete } & $\begin{array}{l}\text { Correlation of liking } \\
\text { and recognition }\end{array}$ & 16 & 0.08 & 0.12 \\
\hline & Liking & 16 & 3.01 & 0.49 \\
\hline & Recognition & 16 & 0.69 & 0.12 \\
\hline & Recognition variability & 16 & 0.45 & 0.06 \\
\hline \multirow[t]{4}{*}{ Colored } & $\begin{array}{l}\text { Correlation of liking } \\
\text { and recognition }\end{array}$ & 24 & -0.03 & 0.10 \\
\hline & Liking & 24 & 2.98 & 0.47 \\
\hline & Recognition & 24 & 0.57 & 0.07 \\
\hline & Recognition variability & 24 & 0.49 & 0.01 \\
\hline \multirow[t]{4}{*}{ Greyscale } & $\begin{array}{l}\text { Correlation of liking } \\
\text { and recognition }\end{array}$ & 24 & 0.09 & 0.13 \\
\hline & Liking & 24 & 2.86 & 0.51 \\
\hline & Recognition & 24 & 0.72 & 0.13 \\
\hline & Recognition variability & 24 & 0.43 & 0.08 \\
\hline
\end{tabular}


Logos that were more accurately recognized as already seen were concrete and presented in greyscale. The unstandardized difference in recognition between colored and greyscale logos equals $b=0.15(\mathrm{p}<0.01)$. In other words, $15 \%$ more logos were accurately recognized when presented in greyscale than in their original colors. The effect is some-

Table 2. Linear regression coefficients

\begin{tabular}{l|c|c|c|c|c}
\hline & & $\mathbf{R}$ & $\mathbf{R 2}$ & Beta & $\mathbf{p}$ \\
\hline Liking & Abstractness & 0.173205 & 0.03 & 0.13 & $>0.05$ \\
\hline & Color & & & -0.12 & $>.05$ \\
\hline & & & & & \\
\hline $\begin{array}{l}\text { Recog- } \\
\text { nition }\end{array}$ & Abstractness & 0.663325 & 0.44 & -0.26 & $<0.05$ \\
\hline & Color & & & -0.6 & $<0.01$ \\
\hline
\end{tabular}

what smaller for the level of abstraction ( $b=0.07$; $p<0.05$ ). Concrete logos are recognized more accurately than abstract logos. Results are graphically presented in the Figure 2.

Finally, exploratory analysis, in which the effect of particular color was examined on liking and recognition, showed that logos with more red color in them are both less liked $(r=-0.46)$ and less recognized $(r=-0.17)$. The effect is opposite for blue and green, which showed a positive correlation with both liking and recognition. It is worth mentioning that due to the exploratory nature of the study and small sample size (only 24 colored logos were analyzed), the sign of the relationship was of greater importance than the statistical significance, although all the relationships were statistically significant, except for the relationship between recognition and the amount of red and blue in a logo. Table 3 contains descriptive statistics and correlation between the amount of a certain color and ratings of liking and recognition.

Figure 2. Relationship between logo liking and logo recognition based on logo color and shape
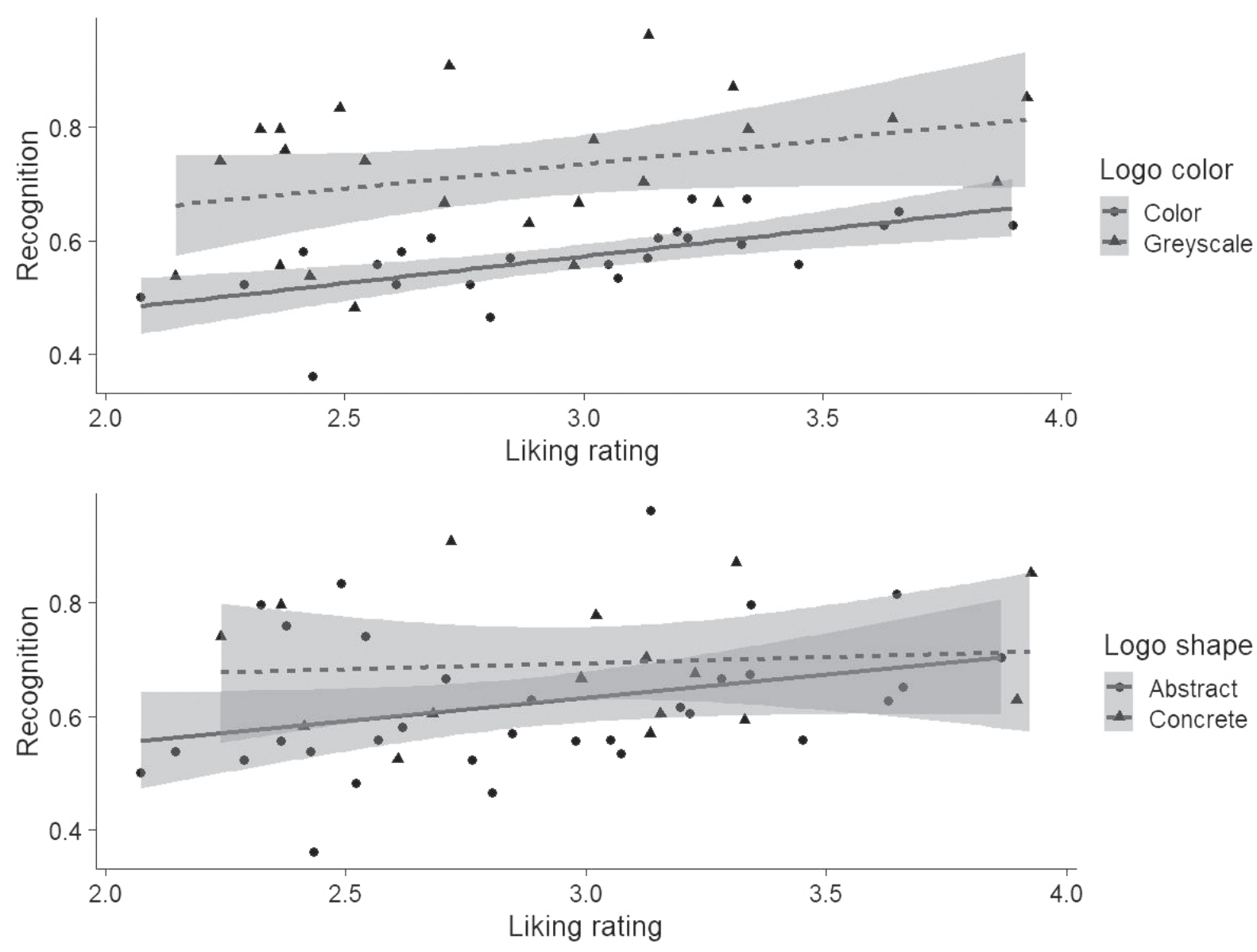
Each logo contains similar amounts of all three colors, with blue being a bit less used. It is important to mention that different combinations of these three colors result in a variety of colors. However, given that these results are among the first to examine color in this numerical way, they can serve as an initial step for future research. Results are graphically presented in Figure 3.

Table 3. Descriptive statistics of the color variables

\begin{tabular}{l|c|c|c|c|c}
\hline & M & SD & Red & Green & Blue \\
\hline Red & 162.4 & 49.41 & & & \\
\hline Green & 155.35 & 30.04 & & & \\
\hline Blue & 132.88 & 37.17 & & & \\
\hline Liking & - & - & $-0.46^{*}$ & $0.60^{* *}$ & $0.52^{* *}$ \\
\hline $\begin{array}{l}\text { Recog- } \\
\text { nition }\end{array}$ & - & - & -0.17 & $0.60^{* *}$ & 0.38 \\
\hline
\end{tabular}

Notes: significance $p<0.05^{*}, p<0.01 * *$
In summary, apart from the H4 (concrete logos will be recognized more accurately), none of the hypotheses were confirmed. Neither the logo's color nor shape affect likeability or recognition. As for the effect of the amount of individual color in a logo, the amount of blue and green in a logo was seen as positive, while the amount of red showed a negative relationship with both recognition and likeability. Discussion of the results and their implications are presented in the following sections.

\section{Discussion}

Most of the findings of the present study are in contradiction with the previous research (Labrecque \& Milne, 2012; Pittard et al., 2007; Wichman et al., 2002). Part of the reason for this contradiction may be accounted for by the differences in the study's design where the present study was run in different context (smartphones), on different samples (students), using rather similar, unknown logos as the

Figure 3. Relationship between amount of primary colors (red, green and blue) in a colored logo and logo liking/recognition.
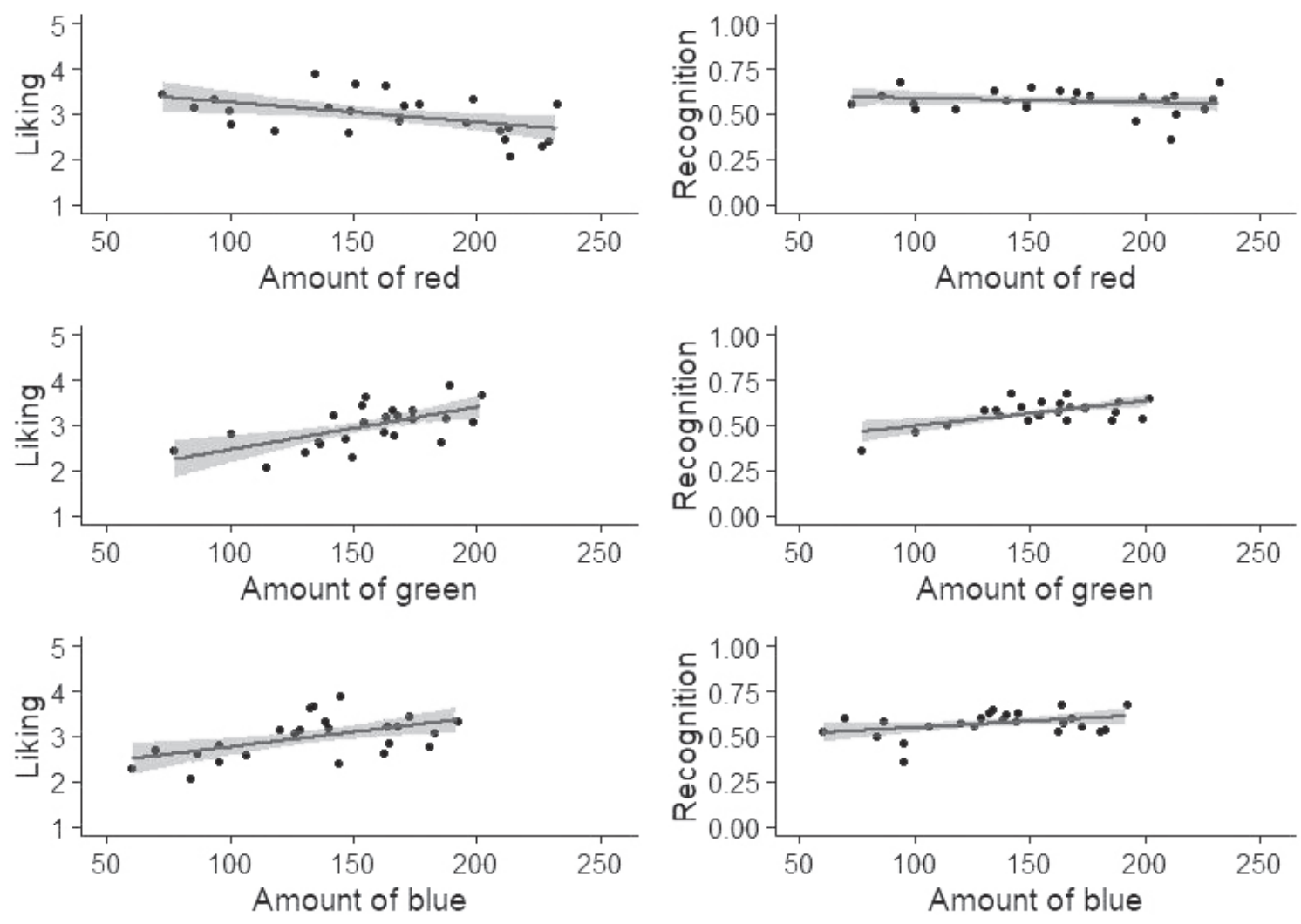

Note: shaded area indicates $95 \%$ CI. 
target stimuli. However, it is important to highlight the fact that previous research has failed to reach an agreement on the logo design effects on important marketing outcomes such as brand awareness. The present study does not deviate from previous ones, but simply extends what is known in the field of brand awareness.

Results of the present research contribute to brand advertising literature in three important ways. First, it is shown that the logo design affects brand awareness. This finding is in line with previous studies on logo design (Henderson \& Cote, 1998; Machado et al., 2015). Logos resembling real life objects were recognized more accurately than abstract logos. Secondly, color showed no effect on either of the brand awareness indicators, contrary to previous research (Labrecque \& Milne, 2012). In fact, logo liking is not influenced by either the shape or color of the logo. Greyscale logos were recognized more accurately than colored logos. Most of the research on logo design was done at least a decade ago (MacInnis \& Jaworski, 1989; Colman, 1995; Henderson and Cote, 1998; Bottomley and Doyle, 2006; Arredondo et al., 2009; Jun et al., 2008; Hynes, 2009). Perhaps this newly observed attentional saturation of the younger consumers, which makes them more prone to remembering stimuli containing fewer pieces of information (Blake et al., 2015), had lead them to better memorizing of lower-information stimuli (greyscale logos) than higher-information stimuli (colored logos).

Finally, as opposed to previous research focused on color, such as finding the right match of colors' properties to different product properties - functionality (Bottomley \& Doyle, 2006), color warmth (Hynes, 2009) or personality dimensions (Labrecque \& Milne, 2012), - this work of research offers an important contribution by showing the effect of the amount of a certain, specific color in colored logos.

Although previous research has shown that logo liking can be predicted based on choosing the right color (Bottomley \& Doyle, 2006), complexity and number of exposures (Miceli et al., 2014), the present results have shown that likeability of the logo is "in the eye of beholder" and not engraved into the logo itself. Authors could not establish what is important for a logo to be perceived as likable, but probable properties can be found in the literature on aesthetics. For example, research on beauty perception showed that people like symmetry since from an evolutionary perspective, it indicates healthy genes (Buss, 2014). The logo symmetry was not measured in this study, but further research that will build upon the present one should incorporate this measure also to test whether it can be observed in other contexts.

Finding that logos when presented in greyscale were recognized more accurately can be explained by the total amount of information a consumer has to remember about the logo.
Research on memory (Atkinson \& Shiffrin, 1968) has shown that the total amount of bits of information one has to remember is negatively related to the accuracy of recognition and recollection. Due to the fact that logos were not tainted with any prior knowledge or experiences by participants, it is therefore improbable that consumers would have something prior to build upon this new information (Bresciani \& Del Ponte, 2017; Machado et al., 2015).

Finally, the negative effect of the amount of red in a logo and lower liking/recognition can be used as a steppingstone for future research. It has been repeatedly shown that consumers positively perceive red color as a color of excitement (Labrecque \& Milne, 2012) and warmth (Hynes, 2009). These findings have been abused by marketing experts who are using it more than other colors in their logos. This behavior increases different logo's saturation with the red color leading to lower liking and lower recognition, possibly due to the inability to distinguish between different logos. Authors are hypothesizing that the positive relationship between blue/green color and liking/recognition can be explained with the same mechanism.

\section{Implications}

We highlight the importance of both brand recognition and brand liking as preconditions for building positive brand outcomes, in the environment that is becoming more and more cluttered. Color has been gaining much attention in advertising and brand literature (Watson et al., 2010; Wedel \& Pieters, 2015), but here, it was shown to be weakly connected with likability, although there was previous research suggesting it. The present paper contributes to the logo design research by limiting the role of color in driving positive brand outcomes. This research clearly shows the need to depart from focusing on color as an independent variable to make a broader approach that considers shape, and more specifically concreteness. It also suggests a new approach to operationalizing color in future research as the average of additive primary colors if research is done using any sort of screen.

The digital environment has faced consumers with many visual stimuli that they need to somehow sort and process, and it is inevitable some of these stimuli are going to be ignored. That is why professionals should engage more resources when deciding on the shape itself if they want their logo to be recognized and liked among their rivals, and not focus solely on logo color (especially red) and expect to stand out based on it. This does not mean they need to ignore colors they use, but quite the opposite - they should use them more carefully. Results of this study suggest they should be more careful when using large amounts of red, and that they should favor green and blue to elicit more favorable outcomes. 


\section{Limitations and further research}

A couple of limitations should be emphasized. Not all students successfully completed both phases of the study due to various reasons that could potentially affect observed results. However, because their ratings were summarized for each logo, this should not affect results in a significant way. Secondly, images used in the study represented logo templates. The reason for this decision was to be certain that participants had not had the chance to experience these logos. For future research, authors should consider using real-life brand logos that are not familiar to their participants. Finally, the color in each logo was not varied, but each logo was presented in its original color or as a greyscale. Future research should take this into account and vary the amount of color for each logo individually to corroborate the exploratory phase of the present study. The fact that authors provided both the logo images and logo description should elicit future research on the topic, since future research can directly compare their interventions for each of the logos. Besides that, no research on color can resist the burden that cultural context carries (Madden et al., 2000), and it would be interesting to see how similar research would turn out in other cultural contexts.

\section{Acknowledgement}

Paper was created by the support of University of Rijeka's Grant; "Dynamic abilities and strategic management" Grant Number: uniri-drustv-18-216, 1376.

Initial version of the paper was presented at the $26^{\text {th }}$ CROMAR Congress, Zagreb, Croatia, December 2019

\section{References}

Aaker, D. A. (1998). Building strong brands. New York: The Free Press.

Adams, F.M., \& Osgood, C.E. (1973). A Cross-Cultural Study of the Affective Meanings of Color. Journal of Cross Cultural Psychology 4(2): 135-56. https://doi.org/10.1177/002202217300400201

Adir, G., Adir, V., \& Pascu, N. E. (2012). Logo Design and the Corporate Identity. Procedia - Social and Behavioral Sciences, 51, $650-654$. https://doi.org/10.1016/j.sbspro.2012.08.218

Arredondo, E., Castaneda, D., Elder, J. P., Slymen, D., \& Dozier, D. (2009). Brand Name Logo Recognition of Fast Food and Healthy Food among Children. Journal of Community Health, 34(1), 73-78. https://doi.org/10.1007/s10900-008-9119-3

Atkinson, R. C., \& Shiffrin, R. M. (1968). Human memory: A proposed system and its control processes. In K. W. Spence \& J.T. Spence (Eds.), The psychology of learning and motivation (pp. 89-195). Academic Press. https://doi.org/10.1016/S0079-7421(08)60422-3

Barthelme, S. (2019). imager: Image Processing Library Based on 'Clmg'. R package version 0.41.2. https://CRAN.R-project.org/ package=imager

Behance, n. d. Retrieved from https://www.behance.net/acongkecil

Belch, M. A., \& Belch, G. E. (2018). Advertising and promotion: An integrated marketing communications perspecti. (11th ed.). New York: McGraw Hill Education.

Bellizzi, J.A. and Hite, R.E. (1992) Environmental Color, Consumer Feelings, and Purchase Likelihood. Psychology and Marketing, 9(5), 347-63. https://doi.org/10.1002/mar.4220090502

Biloš, A., Turkalj, D., \& Kelić, I. (2017). Mobile Learning Usage and Preferences of Vocational Secondary School Students: The cases of Austria, the Czech Republic, and Germany. Naše Gospodarstvo/Our Economy, 63(1), 59-69. https://doi.org/10.1515/ngoe-2017-0006

Blake, A. B., Nazarian, M., \& Castel, A. D. (2015). The Apple of the Mind's Eye: Everyday Attention, Metamemory, and Reconstructive Memory for the Apple Logo. Quarterly Journal of Experimental Psychology, 68, 858-865. https://doi.org/10.1080/17470218.201 4.1002798

Boling, E., Alangari, H., Hajdu, I. M., Guo, M., Gyabak, K., Khlaif, Z., Kizilboga, R., Tomita, K., Alsaif, M., Lachheb, A., Bae, H., Ergulec, F., Zhu, M., Basdogan, M., Buggs, C., Sari, A., \& Techawitthayachinda, R. (2017). Core Judgments of Instructional Designers in Practice. Performance Improvement Quarterly, 30(3), 199-219. https://doi:10.1002/piq.21250

Bottomley, P. A., \& Doyle, J. R. (2006). The interactive effects of colors and products on perceptions of brand logo appropriateness. Marketing Theory, 6(1), 63-83. https://doi.org/10.1177/1470593106061263

Bresciani, S., \& Del Ponte, P. (2017). New brand logo design: Customers' preference for brand name and icon. Journal of Brand Management, 24(5), 375-390. https://doi.org/10.1057/s41262-017-0046-4

Business dictionary. (n.d.). Retrieved fromhttp://www.businessdictionary.com/definition/brand-awareness.html

Buss, D. M. (2014). Evolutionary psychology: The new science of the mind (4. ed., Pearson new international ed). Pearson.

César Machado, J., Vacas-de-Carvalho, L., Costa, P., \& Lencastre, P. (2012). Brand mergers: Examining consumers' responses to name and logo design. Journal of Product \& Brand Management, 21(6), 418-427. https://doi.org/10.1108/10610421211264900

Cheng, K., \& Rolandi, M. (2015). Graphic design for scientists. Nature Nanotechnology, 10(12), 1084-1084. https://doi.org/10.1038/ nnano.2015.290 
Matia Torbarina, Nina Grgurić Čop, Lara Jelenc: Logo Shape and Color as Drivers of Change in Brand Evaluation and Recognition

Colman, A. M. (1995). Sight bites: A study of viewers' impressions of corporate logos in the communications industry. Journal of Market Research Society, 37, 405-415. https://doi.org/10.1177/147078539503700405

Črešnar, R., \& Jevšenak, S. (2019). The Millennials' Effect: How Can Their Personal Values Shape the Future Business Environment of Industry 4.0? Naše Gospodarstvo/Our Economy, 65(1), 57-65. https://doi.org/10.2478/ngoe-2019-0005

Dowling, G. R. (1994). Corporate reputations: strategies for developing the corporate brand. Kogan Page.

eMarketer (2019). Global Instagram Users 2019. Retrieved from https://www.emarketer.com/content/global-instagram-users-2019

Foroudi, P., Melewar, T. C., \& Gupta, S. (2014). Linking corporate logo, corporate image, and reputation: An examination of consumer perceptions in the financial setting. Journal of Business Research, 67(11), 2269-2281. https://doi.org/10.1016/j.jbusres.2014.06.015

Girard, T., Anitsal, M. M., \& Anitsal, I. (2013). The role of logos in building brand awareness and performance: Implications for entrepreneurs. Entrepreneurial Executive, 18, 7-16.

Henderson, P. W., \& Cote, J. A. (1998). Guidelines for Selecting or Modifying Logos. Journal of Marketing, 62, 14-30. https://doi. org/10.1177/002224299806200202

Henderson, P. W., Cote, J. A., Leong, S. M., \& Schmitt, B. (2003). Building strong brands in Asia: Selecting the visual components of image to maximize brand strength. International Journal of Research in Marketing, 20(4), 297-313. https://doi.org/10.1016/j. ijresmar.2003.03.001

Houtkoop, B. L., Chambers, C., Macleod, M., Bishop, D. V. M., Nichols, T. E., \& Wagenmakers, E.-J. (2018). Data Sharing in Psychology: A Survey on Barriers and Preconditions. Advances in Methods and Practices in Psychological Science, 1(1), 70-85. https://doi. org/10.1177/2515245917751886

Hoyer, W. D., \& Brown, S. P. (1990). Effects of Brand Awareness on Choice for a Common, Repeat-Purchase Product. Journal of Consumer Research, 17(2), 141. https://doi.org/10.1086/208544

Hynes, N. (2009). Colour and meaning in corporate logos: An empirical study. Journal of Brand Management, 16(8), 545-555. https:// doi.org/10.1057/bm.2008.5

Jacobs, L., Keown, C., Worthley, R. and Ghymn, K. (1991) ‘Cross-Cultural Color Comparisons: Global Marketers Beware!', International Marketing Review 8(3): 21-30 https://doi.org/10.1108/02651339110137279

Jiang, Y., Gorn, G. J., Galli, M., \& Chattopadhyay, A. (2016). Does Your Company Have the Right Logo? How and Why Circular- and Angular-Logo Shapes Influence Brand Attribute Judgments. Journal of Consumer Research, 42(5), 709-726. https://doi.org/10.1093/ jcr/ucv049

Jun, J. W., Cho, C.-H., \& Kwon, H.J. (2008). The role of affect and cognition in consumer evaluations of corporate visual identity: Perspectives from the United States and Korea. Journal of Brand Management, 15(6), 382-398. https://doi.org/10.1057/bm.2008.11

Khoury, C. K., Kisel, Y., Kantar, M., Barber, E., Ricciardi, V., Klirs, C., Kucera, L., Mehrabi, Z., Johnson, N., Klabin, S., Valiño, Á., Nowakowski, K., Bartomeus, I., Ramankutty, N., Miller, A., Schipanski, M., Gore, M. A., \& Novy, A. (2019). Science-graphic art partnerships to increase research impact. https://doi.org/10.1038/s42003-019-0516-1

Labrecque, L. I., \& Milne, G. R. (2012). Exciting red and competent blue: The importance of color in marketing. Journal of the Academy of Marketing Science, 40(5), 711-727. https://doi.org/10.1007/s11747-010-0245-y

Landis, J.R. \& Koch, G.G. (1977). The measurement of observer agreement for categorical data. Biometrics, 33(1), 159-74. https:// doi.org/10.2307/2529310

Machado, J. C., de Carvalho, L. V., Torres, A., \& Costa, P. (2015). Brand logo design: Examining consumer response to naturalness. Journal of Product \& Brand Management, 24(1), 78-87. https://doi.org/10.1108/JPBM-05-2014-0609

Madden, T.J., Hewett, K. and Roth, M.S. (2000) 'Managing Images in Different Cultures: A Cross-National Study of Color Meanings and Preferences', Journal of International Marketing 8(4): 90-107. https://doi.org/10.1509/jimk.8.4.90.19795

MacInnis, D. J., \& Jaworski, B. J. (1989). Information processing from advertisements: Toward an integrative framework. Journal of Marketing, 53,1-23. https://doi.org/10.1177/002224298905300401

Mandler, G. (1980). Recognizing: The Judgment of Previous Occurrence. Psychological Review, 87, 252-271. https://doi. org/10.1037/0033-295X.87.3.252

Miceli, G. “Nino," Scopelliti, I., Raimondo, M. A., \& Donato, C. (2014). Breaking Through Complexity: Visual and Conceptual Dimensions in Logo Evaluation across Exposures: Visual and conceptual dimensions in logo evaluation across exposures. Psychology \& Marketing, 31(10), 886-899. https://doi.org/10.1002/mar.20741

O'Connor, Z. (2011). Logo colour and differentiation: A new application of environmental colour mapping. Color Research \& Application, 36(1), 55-60. https://doi.org/10.1002/col.20594

Park, C. W., Eisingerich, A. B., Pol, G., \& Park, J. W. (2013). The role of brand logos in firm performance. Journal of Business Research, 66(2), 180-187. https://doi.org/10.1016/j.jbusres.2012.07.011

Peralta, C., \& Moultrie, J. (2010). Collaboration between designers and scientists in the context of scientifc research: A literature review. DS 60: Proceedings of DESIGN 2010, the 11th International Design Conference, 1643-1652

Pittard, N., Ewing, M., \& Jevons, C. (2007). Aesthetic theory and logo design: Examining consumer response to proportion across cultures. International Marketing Review, 24(4), 457-473. https://doi.org/10.1108/02651330710761026

R Core Team (2016). R: A Language and Environment for Statistical Computing [Computer software manual]. Vienna: R Core Team. 
Ridgway, J., \& Myers, B. (2014). A study on brand personality: Consumers' perceptions of colours used in fashion brand logos. International Journal of Fashion Design, Technology and Education, 7(1), 50-57. https://doi.org/10.1080/17543266.2013.877987

Romberg, S., \& Lienhart, R. (2013). Bundle min-hashing for logo recognition. Proceedings of the 3rd ACM Conference on International Conference on Multimedia Retrieval - ICMR '13,113. https://doi.org/10.1145/2461466.2461486

Salgado-Montejo, A., Velasco, C., Olier, J. S., Alvarado, J., \& Spence, C. (2014). Love for logos: Evaluating the congruency between brand symbols and typefaces and their relation to emotional words. Journal of Brand Management, 21(7-8), 635-649. https:// doi.org/10.1057/bm.2014.29

Singh, S. (2006). Impact of color on marketing. Management Decision, 44(6), 783-789. https://doi.org/10.1108/00251740610673332

Tanaka, J. W., \& Presnell, L. M. (1999). Color diagnosticity in object recognition. Perception \& Psychophysics, 61(6), 1140-1153. https://doi.org/10.3758/BF03207619

van den Bosch, A. L. M., de Jong, M. D. T., \& Elving, W. J. L. (2005). How corporate visual identity supports reputation. Corporate Communications: An International Journal, 10(2), 108-116. https://doi.org/10.1108/13563280510596925

van der Lans, R., Cote, J. A., Cole, C. A., Leong, S. M., Smidts, A., Henderson, P. W., Bluemelhuber, C., Bottomley, P. A., Doyle, J. R., Fedorikhin, A., Moorthy, J., Ramaseshan, B., \& Schmitt, B. H. (2009). Cross-National Logo Evaluation Analysis: An Individual-Level Approach. Marketing Science, 28(5), 968-985. https://doi.org/10.1287/mksc.1080.0462

van Grinsven, B., \& Das, E. (2016). I Love You Just The Way You Are: When Large Degrees of Logo Change Hurt Information Processing and Brand Evaluation. In P. Verlegh, H. Voorveld, \& M. Eisend (Eds.), Advances in Advertising Research (Vol. VI) (pp. 379-393). Springer Fachmedien Wiesbaden. https://doi.org/10.1007/978-3-658-10558-7_29

Walsh, M. F., Page Winterich, K., \& Mittal, V. (2010). Do logo redesigns help or hurt your brand? The role of brand commitment. Journal of Product \& Brand Management, 19(2), 76-84. https://doi.org/10.1108/10610421011033421

Walsh, M. F., Page Winterich, K., \& Mittal, V. (2011). How re-designing angular logos to be rounded shapes brand attitude: Consumer brand commitment and self-construal. Journal of Consumer Marketing, 28(6), 438-447. https://doi. org/10.1108/07363761111165958

Watson, S., Thornton, C. G., \& Engelland, B. T. (2010). Skin color shades in advertising to ethnic audiences: The case of African Americans. Journal of Marketing Communications, 16(4), 185-201. https://doi.org/10.1080/13527260802707585

Wedel, M., \& Pieters, R. (2015). The buffer effect: The role of color when advertising exposures are brief and blurred. Marketing Science, 34(1), 134-143. https://doi.org/10.1287/mksc.2014.0882

Wichmann, F.A., Sharpe, L. T., \& Gegenfurtner, K. R. (2002). The contributions of color to recognition memory for natural scenes.Journal of Experimental Psychology: Learning, Memory, and Cognition, 28(3), 509. https://doi.org/10.1037/0278-7393.28.3.509

Wickham, H. (2016). Elegant Graphics for Data Analysis Second Edition. New York, NY: Springer-Verlag

Whitfield, T.W. and Wiltshire, T.J. (1990) ‘Color Psychology: A Critical Review’, Genetic, Social and General Psychology Monographs, 116, 387-411.

World Intellectual Property Organization. (2019). Retrieved fromhttps://www3.wipo.int/branddb/en/

Wurm, L. H., Legge, G. E., Isenberg, L. M., \& Luebker, A. (1993). Color improves object recognition in normal and low vision. Journal of Experimental Psychology: Human perception and performance, 19(4), 899. https://doi.org/10.1037/0096-1523.19.4.899

Ye, G., \& Van Raaij, W. F. (2004). Brand equity: Extending brand awareness and liking with signal detection theory. Journal of marketing communications, 10(2), 95-114. https://doi.org/10.1080/13527260410001693794

Yip, A. W., \& Sinha, P. (2002). Contribution of color to face recognition. Perception, 31(8), 995-1003. https://doi.org/10.1068/p3376 


\section{Oblika in barva logotipa kot gonili sprememb pri vrednotenju in prepoznavnosti znamke}

\section{Izvleček}

Namen pričujoče študije je bil preveriti, če oblika in barva logotipa vplivata na čustveni in kognitivni odziv na nov logotip.V raziskovalnem delu študije smo preučili vpliv količine posamezne primarne barve na dojemanje logotipa. Raziskava je bila izvedena na vzorcu 190 študentov, čigar ocene so bile uporabljene kot merila za opis logotipa. $\checkmark$ študiji sta bili uporabljeni dve neodvisni spremenljivki, tj. oblika logotipa (abstraktna proti konkretni) in barva logotipa (izvirna barva proti sivinskim odtenkom). Rezultati so pokazali, da so logotipe v sivinskih odtenkih in logotipe konkretnih oblik bolje prepoznavali, medtem ko priljubljenost logotipa ni bila povezana z nobeno neodvisno spremenljivko. Opazili smo tudi, da je količina rdeče barve v logotipu negativno povezana, količina modre in zelene barve pa pozitivno povezana s prepoznavnostjo in priljubljenostjo logotipa. Izvajalci naj upoštevajo, da se dejavniki, ki vplivajo na kognitivni in čustveni odziv potrošnikov razlikujejo. Znanstveniki bi lahko razširili ugotovitve te študije glede vpliva količine posamezne barve v logotipu. To je ena prvih raziskav, ki je preučila vpliv barve logotipa na prepoznavnost znamke. Barvo je raziskovala s pomočjo porazdelitve količine posamezne primarne barve. Raziskava je pridobila zunanjo veljavnost s pomočjo testiranja mlajše generacije v njenem značilnem okolju mobilnih telefonov.

Ključne besede: logotip podjetja, prepoznavnost znamke, priljubljenost logotipa, barva logotipa, oblika logotipa 